\title{
EFFICIENCY OF BIOFEEDBACK THERAPY IN COMPLEX TREATMENT OF RHEUMATOID ARTHRITIS PATIENTS
}

\section{Grekhov Rostislav Aleksandrovich}

Doctor of Medical Sciences, Head of Laboratory of Clinical Psychology, Research Institute of Clinical and Experimental Rheumatology rheuma@vlpost.ru

Zemlyachki St., 76, 400138 Volgograd, Russian Federation

\section{Suleymanova Galina Pavlovna}

Candidate of Medical Sciences, Leading Researcher, Laboratory of Clinical Psychology,

Research Institute of Clinical and Experimental Rheumatology

sgppp22@yandex.ru

Zemlyachki St., 76, 400138 Volgograd, Russian Federation

\section{Kharchenko Svetlana Aleksandrovna}

Candidate of Medical Sciences, Leading Researcher, Laboratory of Clinical Psychology,

Research Institute of Clinical and Experimental Rheumatology

sa.kharchenko@mail.ru

Zemlyachki St., 76, 400138 Volgograd, Russian Federation

\section{Ramkhelawon Manoo Bhupendrasingh}

MD, Clinical Resident (Rheumatology),

Research Institute of Clinical and Experimental Rheumatology

kano16@mail.ru

Zemlyachki St., 76, 400138 Volgograd, Russian Federation

\begin{abstract}
Biofeedback is the process of gaining greater awareness of many physiological functions primarily using instruments that provide information on the activity of those systems, with a goal of being able to manipulate them at will. In this work, the analysis of efficiency of biofeedback therapy in treatment of patients suffering from rheumatoid arthritis (RA) is carried out. This analysis was fulfilled by studying the dynamics of clinical, laboratory and psychological
\end{abstract}


(level of subjective control) indices and their comparison in patients of main and control groups before and after the treatment. During the course of combined therapy alongside biofeedback therapy, an increase in analgesic and anti-inflammatory reactions, improved functional capabilities and an improved sign in the formation of personal positive traits were noticed in the patients. Thus, the additional use of biofeedback mechanism in complex treatment of RA patients promotes increased efficiency of medical and rehabilitation process and improvement of level of self-control in the patients.

Key words: biofeedback therapy, rheumatoid arthritis, level of subjective control.

\section{Introduction}

Rheumatoid arthritis (RA) is a serious chronic inflammatory disease of the joints with symptoms of persistent pains, deformation, destruction and dysfunction of the involved joints.

Though the prevalence of RA is not as elevated as compared to osteoarthritis, it is considered as one of the most serious rheumatic diseases due to steadily progressing course which leads to dysfunction, ankylosis and early disability of the joints which goes permanent, and eventually premature death of the patients.

High socio-economic importance of RA is associated with the fact that it mainly affects people of working age and huge amounts of money is spent on the treatment of the patients which ultimately leads to exceeded budget of other chronic diseases.

In regard to this, it is urged to develop actual scientific and practical rationale to be used in RA. Thereupon, substantial application of innovative, safe and effective treatment and rehabilitation technologies is aimed at improving the functionality and adaptive capabilities of patients $[4 ; 6 ; 8 ; 11$; $16 ; 22 ; 23]$.

Very promising in this regard is the use of biofeedback techniques with biofeedback therapy mainly aimed at active participation of the patient in the treatment and training to manage their own physiological functions $[3 ; 5 ; 7 ; 10 ; 17]$. The method of biofeedback therapy is based on the principle of effectiveness of self-regulation of involuntary functions of organs and systems using external feedback.

Thus, biofeedback therapy lets the patient realize the mechanisms of self-control and selfregulation, obtain sustainable positive changes in the activities of the various physiological systems of the body $[1 ; 9 ; 13 ; 15 ; 20 ; 21]$.
The purpose of our work was to increase the efficiency of complex RA treatment by means of biofeedback therapy.

\section{Materials and Methods}

We observed 90 patients with diagnosis of authentic RA: 65 women (72,2\%) and 25 men $(27,8 \%)$ aging from 18 to 66 years. The minimal (1st) degree of RA activity is found in $19(21,1 \%)$, moderate (2nd) degree - in $58(64,4 \%)$ and high (3rd) degree - in $13(14,5 \%)$ patients. Stage I of RA according to the Steinbroker criteria was established in $25(27,8 \%)$ patients, stage II - in $21(23,3 \%)$, stage III - in $44(48,9 \%)$ after Xray examination of joints. The 1st functional class was revealed in $32(35,6 \%)$ patients, 2nd - in 52 $(57,7 \%)$ and only $6(6,7 \%)$ patients had no dysfunction of joints. Slowly progressive course of RA was observed in 63 people (70\%), rapidly progressive - in $27(30 \%)$. Systemic manifestations of the disease were detected in 20 patients $(22,2 \%)$, and are most often observed in patients with moderate to high degrees of activity of the process.

The inclusion criteria comprised verbal consent of the patient; age over 18 years old; correspondence to the diagnostic criteria of the American College of Rheumatology 1991 (ACR); radiological stage I-III of RA by Steinbroker.

The exclusion criteria comprised underaged patients under 18 and over 70 years old; IV stage of RA by Steinbroker; cardiac arrhythmia, the presence of a pacemaker, coagulopathy, and concomitant serious medical pathology.

According to the objectives, RA patients were divided randomly into two groups, according to gender, age and duration of disease: main $(n=$ $60)$ and control $(n=30)$. RA patients of the main and control groups received similar medicament and physiotherapeutic treatment. Besides, patients 
of main group received in addition 12-14 daily sessions of biofeedback therapy using Reacor rehabilitation psycho-physiological complex by "Medicom MTD" (Taganrog), certificated medical products (Registration certificate Ministry of Health of Russian Federation \#97/17-106; Patents of the Russian Federation \#\#2076625, 2102004, 2079284). Training based on the parameters of brain electrical activity (relaxation on electroencephalogram), aimed at increasing alpha activity of the brain was used. Procedure was carried out after single session "Topics of alpha activity" in order to determine the areas of greatest intensity of alpha rhythms.

The psychological status of patients was estimated by means of "level of subjective control" questionnaire [2]. We studied the level of subjective control (LSC) as an integral characteristic, predetermining the personal characteristics of the patient and having a significant impact on the selection of certain individual strategies of behavior [14]. If a person takes most of the responsibility for the events taking place in their life for themselves, explaining them by their conduct, character, ability, it shows the presence of their inner (internalizing) control. If he is inclined to attribute the responsibility for all the surrounding factors, finding the causes in other people around, or in the fate of the case, it indicates the presence of his external (externalities) control.

Efficiency of treatment was estimated by means of OMERACT III unified criteria (Outcome Measures in Arthritis Clinical Trials). The main list of criteria included the following indices: general assessment of patient's condition; physical function; radiological research; expressiveness of pain in joints by VAS (visual analog scale); index of activity of illness - DAS28 (joint count, number of the swollen joints, erythrocytes sedimentation rate (ESR)); the general assessment of health by VAS; criteria of efficiency of anti-rheumatic therapy carried-out ACR; and laboratory indices also (C-reactive protein (CRP) and circulating immune complexes (CIC)). According to recommendations of the European league against rheumatism (EULAR), DAS $>1,2$ corresponds to good response to treatment, $0,6<\mathrm{DAS}<1,2$ - moderate response to treatment; DAS $<0,6$ - absence of effect. ACR 20, ACR 50, ACR 70 indicates respectively $20 \%, 50 \%$ and $70 \%$ of improvement. Statistical processing of the received results was carried out with STATISTICA 6.0 for Windows package and Biostatistics 4.03 for Windows.

\section{Results}

Analysis of the dynamics of compulsory clinical-laboratory parameters effectiveness and their comparison in patients of the main and control groups was carried out. Score of treatment efficacy was assessed by DAS 28 criteria (fig. 1) and ACR (tab. 1).

Evaluating the effectiveness of therapy by ACR 20 criteria in the main group was significantly higher than in control $(p=0,04)$. At the same time, DAS 28 authentically changed in patients of both groups (at $p<0,001$ ), but these changes corresponded to 1,6 points in the main group, and $-1,2$ in the control that corresponds to moderate effect of anti-rheumatic therapy carried out.

The efficiency of biofeedback therapy in complex treatment of RA patients in comparison with conventional treatment, depending on degree of activity and disease stage was analyzed. The efficiency of combined therapy by ACR criteria was higher in patients with 1st and 2nd degree of RA activity, however ACR 50 (чс2 $=4,09$ at $p=$ $0,043)$ with the 1 st degree of RA (Tab. 2) are more often.

At the same time, a positive effect from carried out therapy was observed in patients with the 1st degree of activity of RA, according to

Table 1

Evaluating the effectiveness of treatment of RA patients with ACR criteria

\begin{tabular}{|c|c|c|c|}
\hline $\begin{array}{c}\text { Estimated } \\
\text { parameter }\end{array}$ & $\begin{array}{c}\text { Main group } \\
(n=60)\end{array}$ & $\begin{array}{c}\text { Control group } \\
(n=30)\end{array}$ & $\begin{array}{c}\text { Reliability } \\
\left(\chi^{2}, p\right)\end{array}$ \\
\hline ACR 20 & $39(65 \%)$ & $13(43,3 \%)$ & $\chi^{2}=4,12, p=0,04$ \\
ACR 50 & $12(20 \%)$ & $5(16,6 \%)$ & $\chi^{2}=0,09, p=0,76$ \\
ACR 70 & - & - & - \\
\hline
\end{tabular}


criterion of DAS 28 (Fig. 2) the changes of which corresponded to 1,6 points; the changes in patients with the 2nd degree of activity of RA corresponded to 0,9 points (moderate effect), and in group of patients with $2^{\text {nd }}$ degree of RA activity, and $-0,2$ points that corresponds to absence of effect in patients with the 3rd degree.
The obtained data on set of estimated indicators testify that results of treatment were essentially better in the group of patients with RA the 1 st and the 2 nd degree of activity. In evaluating the effectiveness of biofeedback therapy depending on radiological stages of the disease following results were obtained (Tab. 3, Fig. 3).

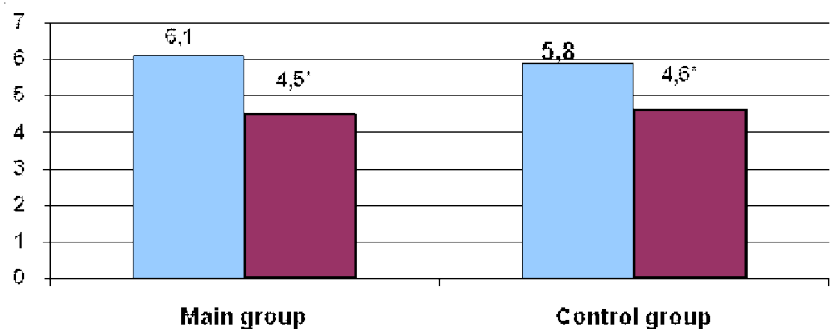

口Prior to treatment

口After treatment

Fig. 1. Evaluating the effectiveness of the treatment of patients with rheumatoid arthritis using the criterion DAS 28

Table 2

Evaluation of treatment efficacy using the ACR criteria, depending on the degree of disease activity

\begin{tabular}{|c|c|c|c|}
\hline \multirow{2}{*}{$\begin{array}{c}\text { Estimated } \\
\text { parameter }\end{array}$} & $\begin{array}{c}\text { I Degree of activity } \\
(n=12)\end{array}$ & $\begin{array}{c}\text { II Degree of activity } \\
(n=39)\end{array}$ & $\begin{array}{c}\text { III Degree of activity } \\
(n=9)\end{array}$ \\
\cline { 2 - 4 } & \multicolumn{3}{|c|}{ (absolute value and percentage) } \\
\hline ACR 20 & $6(50 \%)$ & $28(71,8 \%)$ & $6(66,6 \%)$ \\
ACR 50 & $6(50 \%)$ & $6(15,3 \%)$ & - \\
ACR 70 & - & - & - \\
\hline
\end{tabular}

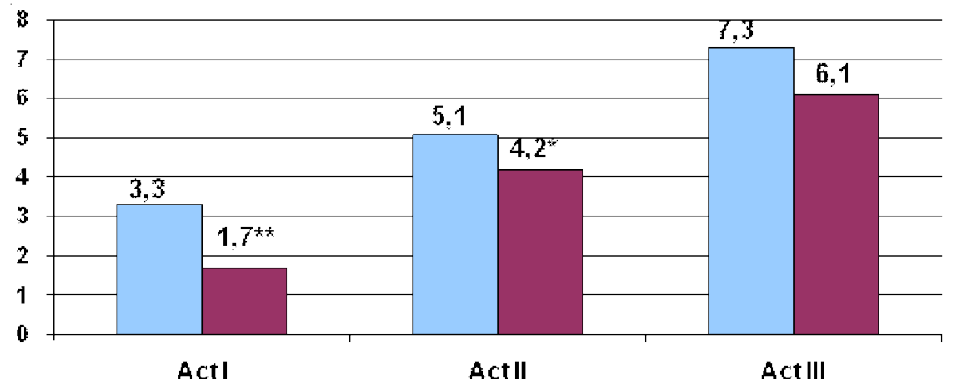

ᄃ Prior to treatment

n After treatment

Fig. 2. Evaluating the effectiveness of the treatment of patients with rheumatoid arthritis using the criterion DAS 28 depending on the degree of disease activity

Note. ${ }^{*}-p<0,01,{ }^{*} *-p<0,001$.

Table 3

Evaluating the effectiveness of treatment of RA patients with ACR criteria, depending on the stage of the disease

\begin{tabular}{|c|c|c|c|}
\hline \multirow{2}{*}{$\begin{array}{c}\text { Estimated } \\
\text { parameter }\end{array}$} & $\begin{array}{c}\text { I Stage } \\
(n=16)\end{array}$ & $\begin{array}{c}\text { II Stage } \\
(n=14)\end{array}$ & $\begin{array}{c}\text { III Stage } \\
(n=30)\end{array}$ \\
\cline { 2 - 4 } & \multicolumn{3}{|c|}{$($ absolute value and percentage) } \\
\hline ACR 20 & $9(56,25 \%)$ & $9(64,28 \%)$ & $19(63,3 \%)$ \\
ACR 50 & $7(43,75 \%)$ & $5(35,72 \%)$ & - \\
ACR 70 & - & - & - \\
\hline
\end{tabular}




\section{ПСИХОЛОГИЯ И ПСИХОФИЗИОЛОГИЯ}

On the basis of the data received it is possible to draw a conclusion that efficiency of the combined therapy by criteria of ACR is higher in patients with I and the II stage of RA. Patients with stage I RA, a change according to criterion DAS 28, scores corresponded to 1,5 at $p<0,001$, the group of patients with stage II RA, these changes conform 1,1 scores $(p<0,05)$, and with III $-0,5(p<0,05)$. On sets of estimated indicators, results of treatment were essentially better in group of RA patients with I radiographic stage. While the use of biofeedback therapy in the treatment of patients with stage III RA has noy been a success. The dynamics of indicators of level of subjective control in the main and control groups (Fig. 4, 5) was also studied.

In the main group of patients, after using the method of biofeedback therapy, a significantly

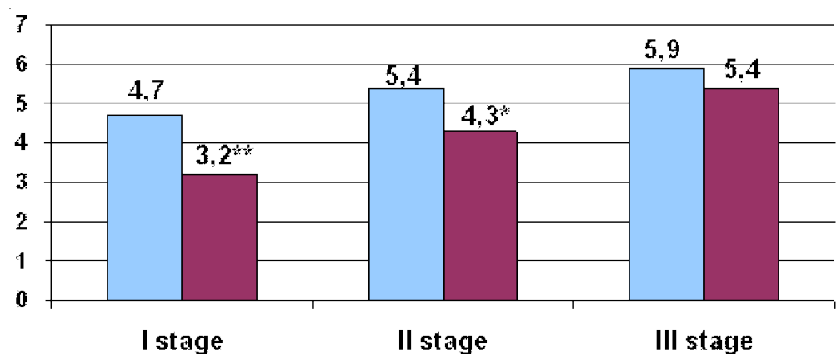

$\square$ Prior to treatment

$\square$ After treatment

Fig. 3. Evaluating the effectiveness of treatment in patients with rheumatoid arthritis using the criterion DAS 28 , depending on the stage of the disease

Note. $*_{-} p<0,05, * *-p<0,001$.

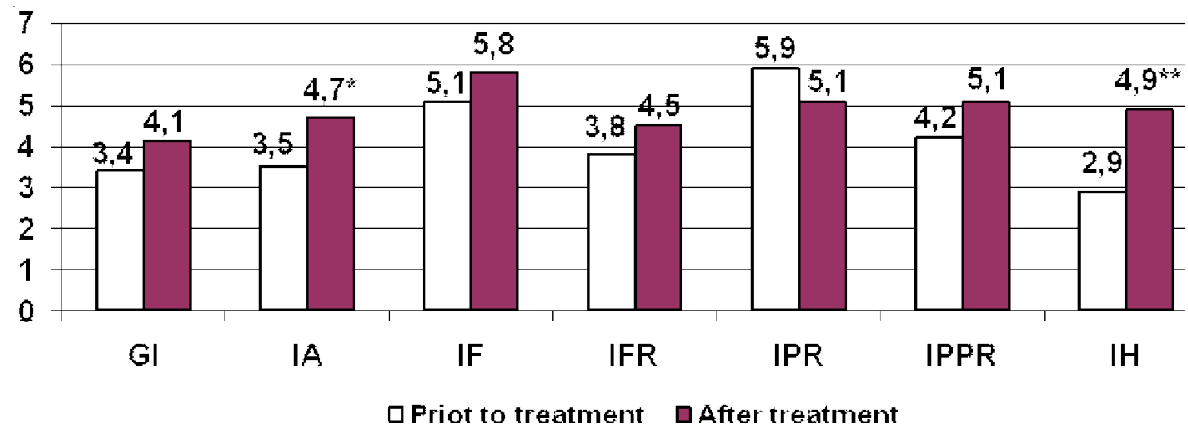

Fig. 4. Indicators of subjective control in patients with rheumatoid arthritis, the main group before and after treatment:

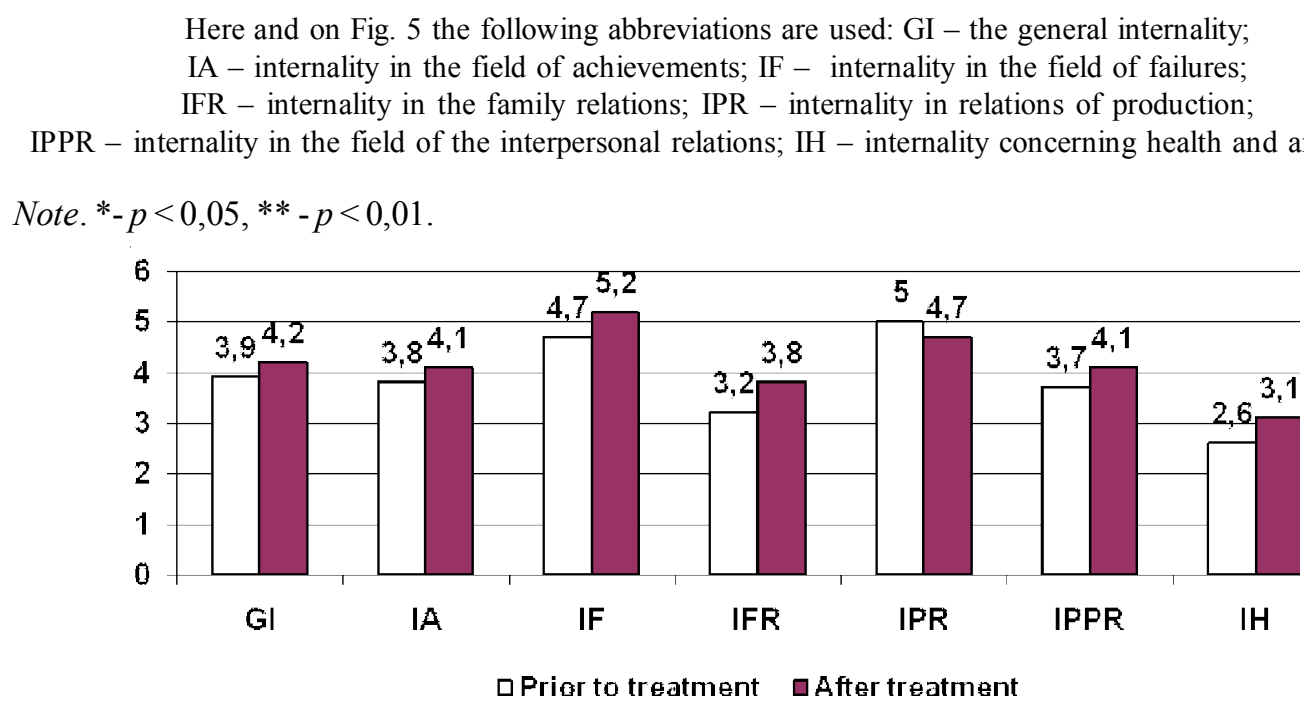

Fig. 5. Indicators of subjective control in RA patients of the control group before and after treatment 
strong trend towards internality (performance improvement) on the scale of developments in the field and relationship to the disease was seen. In the group of patients treated only with conventional therapy, the results of the dynamics of the USK were not statistically significant.

\section{Discussion}

Thus, complex treatment, including the use of the method of biofeedback therapy was more effective than the traditional treatment of RA patients. When using biofeedback therapy there was a decrease of pain intensity eventually bringing to relief and a decrease in exudative phenomena in the joints, increased joint mobility, and improved overall well-being of patients. Apparently, the mechanism of therapeutic effect of biofeedback therapy should be found not only in changes related to physiological systems. One of the possible mechanisms of therapeutic action is the effect of cognitive experiences biofeedback training in self-control, the re-orientation of external level of subjective control on internalising (which is confirmed by the results of the present study). With the help of biofeedback therapy, patients gained a sense of controllability of their illness, which before they were not able to do and hence adhere to stricter treatment regime, taking responsibility for their health.

Perhaps these aspects of biofeedback therapy lead to improved results of the therapeutic process. We can say that in this case it is not the degree of physiological change that serves as a critical value, but the degree of belief in the patient to take control over the disease symptoms. Biofeedback training gives the patient the opportunity to receive positive reinforcement through feedback, informing them about the development of skills of self-regulation, the patient brings a sense of satisfaction associated with the completion of self-voluntary efforts, and the awareness of the possibility of improvement. The sense of hopelessness and helplessness is replaced by feeling of the prospect, new possibilities that promote the reduction of pain syndrome and a decrease in depression and frustration $[12 ; 18 ; 19]$.

It should be noted that the few cases of ineffectiveness of biofeedback therapy were observed only in patients with maximum activity and stage III of radiographic RA as the stage of progression of the rheumatoid process was accompanied by the development of irreversible organic lesions of joints and high impaired immunological activity requiring use of powerful immunosuppressive agents, hormonal and, methods of extracorporeal therapy.

\section{Conclusions}

Application of biofeedback therapy enhances the effectiveness of integrated treatment of RA patients by reducing pain and joint syndrome, promotes active and conscious participation of a person in the course of therapy on the basis of self-regulation and self-control, and therefore mobilized will potential and increased self-esteem of patients. The method of biofeedback therapy is an affordable and safe treatment that can be recommended for widespread use in rheumatology practice.

\section{REFERENCES}

1. Achterberg J., McGraw P., Lawlis G.F. Rheumatoid Arthritis: a Study of Relaxation and Temperature Biofeedback Training as an Adjunctive Therapy. Biofeedback Self.-Regul., 1981, June, no. 6 (2), pp. 207-223.

2. Bazhin E.F., Galynkin E.A., Etkind A.M. Questionnaire of Level of Subjective Control (USK). Moscow, Mysl Publ., 1993. 15 p.

3. Frank D.L., Khorshid L., Kiffer J.F., Moravec C.S., McKee M.G. Biofeedback in Medicine: Who, When, Why and How? Ment. Health Fam. Med., 2010, June, no. 7 (2), pp. 85-91.

4. Bradley L.A. Effect of Cognitive-Behavioral Therapy on Pain Behavior of Rheumatoid Arthritis (RA) Patients: Preliminary Outcomes. Scandinavian Journal of Behaviour Therapy, 1985, no. 14 (2), pp. 51-64.

5. Corrado P., Gottlieb H., Abdelhamid M.H. The Effect of Biofeedback and Relaxation Training on Anxiety and Somatic Complaints in Chronic Pain Patients. American Journal of Pain Management, 2003, no. 13, pp. 133-139.

6. Bradley L.A., Young L.D., Turner R.A., Agudelo C.A., McDaniel L.K., et al. Effects of Psychological Therapy on Pain Behavior of Rheumatoid Arthritis Patients: Treatment Outcome and Six-Month Followup. Arthritis and Rheumatism, 1987, no. 30 (10), pp. 1105-1114.

7. Flor H., Haag G., Turk D.C., Koehler H. Efficacy of EMG Biofeedback, Pseudotherapy, and Conventional Medical Treatment for Chronic Rheumatic Back Pain. Pain, 1983, no. 17(1), pp. 21-31. 
8. Ernst E. Complementary Therapies for Pain Management: an Evidence-Based Approach. Elsevier Science, 2007. 372 p.

9. Lavigne J.V., Ross C.K., Berry S.L., Hayford J.R. Evaluation of a Psychological Treatment Package for Treating Pain in Ju Venile Rheumatoid Arthritis. Arthritis Care \& Research, 1992, no. 5(2), pp. 101-110.

10. Flor H., Haag G., Turk D.C. Long-Term Efficacy of EMG Biofeedback for Chronic Rheumatic Back Pain. Pain, 1986, no. 27 (2), pp. 195-202.

11. Freeman L.W. Mosby's Complementary \& Alternative Medicine: a Research-Based Approach. Elsevier Science, 2008. 640 p.

12. Grekhov R.A. Psychosomatic Ratios and an Internal Picture of an Illness in Rheumatologic Patients: Dr. med. sci. abs. diss. Volgograd, 2010. 51 p. (in Russian).

13. Mavliyeva G.M., Stepanov A.A., Bodrov R.A. Influence of Biological Feedback on Neurodynamics and Cerebral Hemodynamics in Patients With Pathology of Cervical Spine. Materials of the $2^{\text {nd }}$ International Congress "Regenerative Medicine and Rehabilitation”. Moscow, 2005.

14. Muzdybaev K. Responsibility Psychology. Leningrad, 1983. 240 p. (in Russian).

15. Nitz J.C., Luparia L. The Use of EMG Biofeedback in Quadriceps Strengthening Exercise for Rheumatoid Arthritis Patients: a Clinical Trial. Physiotherapy, 1983, August, vol. 29, iss. 4, pp. 127-132.
16. Astin J.A., Beckner W., Soeken K., Hochberg M.C., Berman B. Psychological Interventions for Rheumatoid Arthritis: a MetaAnalysis of Randomized Controlled Trials. Arthritis and Rheumatism, 2002, no. 47 (3), pp. 291-302.

17. Schwartz M.S., Andrasik F. Biofeedback: $a$ Practitioner's Guide. New York, Guilford Press, 2003.

18. Shtark M.B. Biomanagement-2: Theory and Practice. Novosibirsk, 1993, no. 2, p. 1-11.

19. Shtark M.B., Skok A.B. Biomanagement-3: Theory and Practice. Novosibirsk, 1998, pp. 131141.

20. Tchernikov L.A., Nekrasov E.M., Toropova N.T. Biomanagement-2: Theory and Practice. Novosibirsk, IMBK WITH Russian Academy of Medical Science, 1993, pp. 125-127.

21. Tchernikov L.A., Komynina E.M. Biomanagement-3: Theory and Practice. Novosibirsk, 1998, pp. 81-87.

22. Young L.D., Bradley L.A., Turner R.A. Decrease in Health Care Resource Utilization in Patients With Rheumatoid Arthritis Following a Cognitive Behavioral Intervention. Biofeedback and Self-Regulation, 1995, no. 20, pp. 259-268.

23. Young L.D., Bradley L.A., Turner R.A. Decreases in Health Care Resource Utilization in Patients With Rheumatoid Arthritis Following a Cognitive Behavioral Intervention. Biofeedback and SelfRegulation, 1995, no. 20 (3), pp. 259-268.

\section{ЭФФЕКТИВНОСТЬ БИОЛОГИЧЕСКОЙ ОБРАТНОЙ СВЯЗИ В КОМПЛЕКСНОМ ЛЕЧЕНИИ БОЛЬНЫХ РЕВМАТОИДНЫМ АРТРИТОМ}

\section{Грехов Ростислав Александрович}

Доктор медицинских наук, заведующий лабораторией клинической психологии, Научно-исследовательский институт клинической и экспериментальной ревматологии rheuma@vlpost.ru ул. Землячки, 76, 400138 г. Волгоград, Российская Федерация

\section{Сулейманова Галина Павловна}

Кандидат медицинских наук, ведущий научный сотрудник лаборатории клинической психологии, Научно-исследовательский институт клинической и экспериментальной ревматологии sgppp22@yandex.ru ул. Землячки, 76, 400138 г. Волгоград, Российская Федерация

\section{Харченко Светлана Александровна}

Кандидат медицинских наук, ведущий научный сотрудник лаборатории клинической психологии, Научно-исследовательский институт клинической и экспериментальной ревматологии sa.kharchenko@mail.ru ул. Землячки, 76, 400138 г. Волгоград, Российская Федерация 


\section{Рамкхелавон Ману Бхупендрасинг}

Клинический ординатор,

Научно-исследовательский институт клинической и экспериментальной ревматологии kano16@mail.ru

ул. Землячки, 76, 400138 г. Волгоград, Российская Федерация

Аннотация. Биологическая обратная связь заключается в процессе получения пациентом большей осведомленности о многих физиологических функциях, прежде всего с использованием инструментов, которые предоставляют ему информацию о деятельности этих систем, с целью получения возможности управлять ими по своему усмотрению. В этой работе был проведен анализ эффективности терапии с использованием биологической обратной связи при лечении пациентов, страдающих ревматоидным артритом (РА), путем изучения динамики клинических, лабораторных и психологических (уровень субъективного контроля) показателей и их сравнения у пациентов основной и контрольной групп до и после лечения. В ходе комплексной терапии с использованием метода биологической обратной связи у пациентов отмечалось увеличение анальгетических и противовоспалительных реакций, улучшение функциональных возможностей и улучшение симптомов формирования положительных личностных черт. Таким образом, дополнительное использование механизмов биологической обратной связи в комплексном лечении пациентов с ревматоидным артритом содействует повышению эффективности лечебного и реабилитационного процесса и повышению уровня самоконтроля у больных.

Ключевые слова: БОС-терапия, ревматоидный артрит, уровень субъективного контроля. 